\title{
DISCURSO DE POSSE DO \\ PROF. DR. AGERSON TABOSA \\ PINTO (FA7) NO INSTITUTO DE ESTUDOS IBÉRICOS
}

Ao dizer-vos, neste instante, do contentamento de que estou possuído por vossa recepção no Instituto de Estudos Ibéricos e ao agradecer-vos o gesto de confiança e fidalguia, peço-vos permissão para divagar um pouco, primeiro sobre a viagem que me trouxe à Ibéria, e, em segundo lugar, sobre os efeitos positivos decorrentes do processo de aculturação ou da globalização.

1. Foi em 1994. Estava em Xalapa, México, participando de Congresso de Direito Romano, quando o professor espanhol Gerardo Turiel de Castro nos comunicou a criação, em Oviedo, da Asociación Iberoamericana de Derecho Romano, e já nos convidou, logo para 1995, a participar, em Granada, do primeiro congresso da entidade, inaugurando uma série, que, este ano, alcançará sua $13^{\mathrm{a}}$ edição. Como professores de Direito Romano, eu e minha esposa, aqui presente, estivemos lá, quando conhecemos muitos ilustres professores espanhóis, entre os quais estava o catedrático de Direito Romano da Universidade de Vigo, Dr. Luís Rodríguez Ennes.

Os dois congressos seguintes foram em Múrcia (1996) e em León (1997).

O IV Congreso Iberoamericano de Derecho Romano foi celebrado em Ourense, em 1998, quando fomos cumulados de gentilezas pelos nossos colegas da Espanha, com destaque para os professores Luís Ennes e Maria José Bravo.

Buenos Aires (1999), Madrid (2000) e Burgos (2001) foram as cidades que sediaram os três seguintes congressos da série.

Penso que, como prêmio por minha assiduidade, pois havia comparecido a todos os congressos promovidos por nossa Associação, fui o primeiro brasileiro a ser eleito para sua Junta Directiva, como estou sendo o primeiro brasileiro a ingressar neste Instituto, como membro titular.

Em 2002, minha cidade, Fortaleza, sediou o VIII Congresso, quando tivemos o prazer não só de reabraçar nossos colegas da Espanha, da Argentina e outros países da América Latina, mas também de inscrever, como associado, e de ouvir, como conferencista, o primeiro professor de Portugal, Dr. Antonio dos Santos Justo, catedrático de Direito Romano da Universidade de Coimbra. O ilustre mestre lusíada, que participou de todos os congressos subseqüentes - Huelva (2003), 
e Alicante - Elche (2004), empolgou-se com o nosso movimento, chegando a dirigir o Congresso de Coimbra, em 2005, e inaugurou uma nova fase - incipit vita nova - no relacionamento de romanistas espanhóis e portugueses.

2. Que significação tem a abertura das portas do Instituto de Estudos Ibéricos a outras regiões que não integram a Ibéria européia continental?

Os três objetivos a que se propõe estatutariamente o Instituto - realizar e difundir estudos nas áreas do Direito e das Ciências Sociais; promover cursos, conferências, seminários e congressos nos campos dessas ciências; e editar livros e periódicos que divulguem os estudos realizados pelo Instituto - todos esses objetivos, para serem difundidos e alcançados, precisam de contatos, de interação, de intercambio e de cooperação internacional. Não é por acaso, mas por facilitar o intercambio pessoal e grupal, que cidades, desde as mais priscas eras até os dias de hoje, têm sido edificadas nas margens ou desembocaduras dos rios. Aí estão, para comprová-lo, as cidades banhadas pelo Tibre, o Tamisa, o Sena, o Danúbio, o Tejo, o Reno, o Mississipi-Missouri e o Yang-Tse-Kiang. ${ }^{1}$

Não é por acaso, mas por favorecer a densidade dos aglomerados humanos, que, das 43 cidades mais populosas do mundo, apenas 8 estão fora da faixa entre 30 e 50 graus de latitude norte. Aí estão, dentro dessa faixa, Los Angeles, Nova Iorque, Madrid, Paris, Londres, Roma, Moscou, Pequim e Tókio. ${ }^{2}$

A motivação para intercâmbio entre os povos pode ser de natureza econômica, mas não só e nem sempre. O professor Luís Rodriguez Ennes provou que o interesse dos romanos pelas terras ibéricas primitivas estava na riqueza de suas jazidas de ouro e de prata, estava, segundo o poeta, na auri sacra fames, ou seja, na execrável fome do ouro. ${ }^{3}$ Mas também é fácil provar que dos processos sociais, gerados com a exploração mineral, também os ibéricos muito se beneficiaram. ${ }^{4}$

Quando Horácio disse que Graecia capta ferum victorem cepit et artes intulit agresti Latio, ele já sabia que pelas leis que regulam o processo da aculturação, quando duas culturas se encontram, predomina, em geral a superior, mas nesta sempre ficam marcas da cultura inferior. Assim, mesmo vencida, a Grécia implantou suas artes no Lácio vitorioso. Igualmente, em razão das invasões dos godos e visigodos, o direito romano aculturado modernamente não é mais o direito romano justinianeu, do Corpus Juris Civilis, o direito romano genuíno, mas o direito romano-germânico, assim como os mouros, mesmo vencidos, deixaram marcas de sua cultura na cultura dos povos vencedores.

Por isso é que nós brasileiros não nos acabrunhamos com a invasão de dinheiro espanhol no Brasil. Em 1998, chegaram a 9,6 bilhões de dólares os investimentos espanhóis diretos no Brasil, o que representou $27 \%$ do total dos investimentos da Espanha, realizados no mundo.5 Segundo recente anúncio de Cesar Alierta, presidente mundial do grupo espanhol da Telefônica, essa empresa 
já investiu, desde a privatização em 1998, R\$28,9 bilhões e ainda investirá, até 2010, mais R\$ 15 bilhões ${ }^{6}$.

Para nós brasileiros, pelo menos para os brasileiros que prezamos o estudo, mais do que saber quem primeiro chegou ao Brasil, se Pinzon ou Cabral, ou de que nacionalidade é o dinheiro que nos ajuda a crescer, a nós nos interessa mais saber as origens de nossa cultura comum, sua perfeita caracterização, pois queremos mantê-la una e integrada e queremos constantemente enriquecê-la.

Por fim, cremos com o dr. Sousa Magalhães, "que existe uma ampla convergência no sentido de que a Galícia e o Norte de Portugal podem, dentro dos seus respectivos Estados de pertença, afirmar as suas raízes comuns e tentar contribuir para que Portugal e Espanha possam acentuar esta vertente atlântica, permitindo que o tal "admirável mundo novo", seja mais culto, tolerante e solidário".?

Fontoura, Afro do Amaral, Introdução à Sociologia, $4^{\mathrm{a}}$ ed., Porto Alegre, Globo, 1966, p. 113.

2 Tabosa, Agerson, Sociologia Geral e Jurídica, Fortaleza, Fa7, 2006, p. 81

3 Virgílio, Eneida, Livro III, v. 57. Ennes, Luiz Rodriguez. Las Explotaciones Mineras y la Romanización de Gallaecia. In: Villar, Afonso Murillo (ccord.). Estudios de Derecho Romano en Memoria de Benito M. Reymundo Yanes. Burgos: Universidade de Burgos, II, p. 305-327; e Gallaecia: Romanización y Ordenación del territorio. In Buján, Antonio Fernández de (director), Derecho Administrativo Histórico. Santiago de Compostela: Xunta de Galícia, 2005, p. 355-392.

${ }^{4}$ Horácio, Epístolas, II, 1

Boletim da Sobeet, ano III, $\mathrm{n}^{\mathrm{o}}$ 31, jan. 2005,1

Folha de S. Paulo, edição de 18 de janeiro de 2007, B 1

"Distinción de la Abogacia Española, concedida al Dr. Sousa Magalhães".Discurso do agraciado, Instituto de Estudos Ibéricos, Anuário de 2003, p. 75 